\title{
Influence of Selected Organic Manures on Soil Health and Yield Sustainability of Western Himalaya Vegetable Production Systems
}

\author{
D.K. Parmar*, D.R. Thakur and Gurudev Singh \\ CSK Himachal Pradesh Krishi Vishvavidayalaya, Hill Agricultural Research and Extension \\ Centre, Bajaura 175125, District Kullu, India \\ *Corresponding author
}

\begin{tabular}{|c|c|}
\hline \multicolumn{2}{|r|}{ A B S T R A C T } \\
\hline & \multirow{6}{*}{$\begin{array}{l}\text { A field study from } 2009 \text { to } 2013 \text { was carried out to investigate the effect of organic manure } \\
\text { including panchagavya and biodynamic spray on commonly used tomato-coriander-pea } \\
\text { and cauliflower-cauliflower-peacropping system in Western Himalaya. The results } \\
\text { revealed that cropping systems differ significantly in terms of soil microbial properties. } \\
\text { The tomato-coriander-pea crop sequence recorded higher soil carbon biomass and } \\
\text { population of soil bacteria, fungi and actinomycetes as compared to cauliflower- } \\
\text { cauliflower-pea crop sequence. The tomato-coriander-pea had enhanced activity of } \\
\text { phosphatase enzyme in soil. Soil pH and availability of micronutrients was not influenced } \\
\text { under cropping systems, however, organic carbon and availability of major nutrients was } \\
\text { significantly improved in tomato-coriander-pea sequence than cauliflower-cauliflower-pea. } \\
\text { The highest productivity and net returns were observed for tomato-coriander-pea as } \\
\text { compared to cauliflower-cauliflower-pea sequence. Different nutrient sources significantly } \\
\text { influenced measured soil and plant parameters except soil pH. The maximum increase in } \\
\text { organic carbon, soil carbon biomass, bacteria, fungi, actinomycetes and phosphatase } \\
\text { enzyme, availability of major and micronutrients, yield and net returns were observed with } \\
\text { farmyard manure application followed by biodynamic and panchagavaya spray as } \\
\text { compared to control. }\end{array}$} \\
\hline Keywords & \\
\hline $\begin{array}{l}\text { Environmental } \\
\text { issue, Growing } \\
\text { awareness, Field } \\
\text { study }\end{array}$ & \\
\hline Article Info & \\
\hline & \\
\hline & \\
\hline
\end{tabular}

\section{Introduction}

Growing awareness of health and environmental issues in agriculture has demanded production of organic food, which is emerging as an attractive source of rural income generation (Bhattacharya and Chakraborty, 2005). The green revolution in India brought about a spectacular increase in agricultural production with introduction of high yielding varieties of crops, extension of irrigated areas, use of chemical fertilizers and pesticides and enhancing of cropping intensity which made the country self -sufficient in food production. However, during green revolution process, the use of organic manures, which was hitherto the main practice in Indian agriculture, diminished considerably (Gupta et al., 2005). The harmful effects of chemical based farming such as accumulation of excessive amount of nitrate in the water, occurrence of a sharp decline in the ground water level and its contamination with heavy metals, deposition of phosphate along with 
nitrate in the aquatic ecosystems, presence of pesticidal residues in various food stuffs, caused a number of problems in human beings, animals and plants. Rise in resistance of pests to chemical pesticides, occurrence of multi-nutrient deficiencies in soils, thereby resulting into an overall decline in their production capacity under intensive fertilizer use are the other deleterious effects created by the green revolution process. The addition of organic nutrients to soil could be a promising technology for reducing the usage of synthetic fertilizers (Karthigeyanm and Alagesan, 2011). Therefore, this study was carried out to assess the effect of organic manures including foliar spray of panchagavya and biodynamic on the yield and soil properties of two commonly used vegetable production systems in Western Himalaya.

\section{Materials and Methods}

A field experiment was conducted from 2009 - 2013 to investigate the effect of organic manure including panchagvya and biodynamic spray on vegetable yield, economic, mineral concentration and soil properties. The experiment was situated at the experimental farm of the Himachal Pradesh Agricultural University, Hill Agricultural Research and Extension Centre near Kullu-Manali, India $\left(31.8^{\mathrm{O}} \mathrm{N}\right.$ latitude, $77^{\mathrm{O}} \mathrm{E}$ longitude at an altitude of $1090 \mathrm{~m}$ above sea level, where annual rainfall varies from 1000-1200 mm). The experiment consisted of two cropping systems $\left[\mathrm{CS}_{1}=\right.$ Tomato (Lycopersicon esculentum var. commune) - coriander (Coriandrum sativum L.) -pea (Pisum sativum var. arvense) and $\mathrm{CS}_{2=}$ cauliflower (Brassica oleraceavar. brotytis) -cauliflower (Brassica oleracea var. brotytis)-pea (Pisum sativum var. arvense)] and five nutrient sources $\left[\mathrm{NS}_{1}=\right.$ rockphosphate enriched FYM + vermicompost (1:1); $\mathrm{NS}_{2}=$ farmyard manure $+\mathrm{BD} 501$ spray; $\mathrm{NS}_{3}=$ $\mathrm{NS}_{1}+$ panchagavya spray; $\mathrm{NS}_{4}=\mathrm{NS}_{2}$ +panchagavya spray and $\mathrm{NS}_{5}$-control]. The cropping systems were placed in main plots and nutrient sources in sub plots in a split plot design with three replications. The experimental soils had initial $\mathrm{pH}$ 5.5; organic carbon $0.45 \%$; bulk density $1.62 \mathrm{~g} / \mathrm{cc}$. They contained $\mathrm{N} 146 \mathrm{Kg} / \mathrm{ha}, \mathrm{P}_{2} \mathrm{O}_{5} 43 \mathrm{Kg} / \mathrm{ha}$ and $\mathrm{K}_{2} \mathrm{O} 121 \mathrm{Kg} / \mathrm{ha}$. Micronutrient Fe, Mn, Zn and $\mathrm{Cu}$ were $30,1.03,1.20$ and $0.12 \mathrm{ppm}$, respectively. Crops were transplanted/ sown in a fixed plot of $54 \mathrm{~m}^{2}$ following recommended package of practices. The irrigation was given as per requirement. The weeds were managed manually. The bio-pesticides (Trichoderma viride and Pseudomonas fluorescence) and bio-insecticide (Azardarachtin @ 0.15\% EC) were used for plant protection purposes. The FYM used in the study contained $2.35 \% \mathrm{~N}$, $0.27 \% \mathrm{P}, 2.39 \% \mathrm{~K}$ and vermicompost contained $1.68 \% \mathrm{~N}, 0.20 \% \mathrm{P}$, and $1.28 \% \mathrm{~K}$ and was applied as per treatment equivalent to recommended fertilizer doses at the time of field preparation. Panchagavya, an organic formulation, was prepared with $5 \mathrm{~kg}$ cow dung, $1 \mathrm{~kg}$ clarified butter, $5 \mathrm{~L}$ cow urine, $3 \mathrm{~L}$ curd, $3 \mathrm{~L}$ milk, and $5 \mathrm{~L}$ water. These materials were mixed together and stirred daily for 15 days. A dilution of 1:10was used for spraying on crops at 15 days interval starting just after appearance of flowering. Biodynamic 501 sourced Eco-Agricultural Research Foundation; Mysore, India was sprayed @ 2.5 $\mathrm{g} / 40 \mathrm{~L}$ of water as a fine mist on the plant foliage before sunrise as per bio dynamic calendar on a moon opposite Saturn day. Composite soil samples $(0-15 \mathrm{~cm})$ collected after every crop cycle were analyzed for some soil chemical and physical properties. Soil microbiological properties were determined initially and after four crop cycles. The soil organic carbon was determined by wet oxidation method (Walkley and Black, 1934); available $\mathrm{N}$ by alkaline permanganate method (Subbiah and Asija, 1956); available phosphorus by Olsen's method (Olsen et al., 1954); available potassium by flame photometer (Jackson, 1973) and soil bulk 
density using method of Singh (1980). The enumeration of total bacteria, fungi, actinomycetes in fresh rhizosphere soil samples was carried out by following serial dilution plate count technique using nutrient agar for bacteria, Martin's Rose Bengal agar for fungi (Martin, 1950), Kuster's agar (Kusterand Williams, 1964) for actinomycetes. Alkaline phosphatase activity was measured by estimating concentration of P- nitro phenol a hydrolyzed product of substrate P-nitro phenyl phosphate (PNP). The yield of whole cropping system was determined by summing up yield data of three crops and expressed as $\mathrm{q} / \mathrm{ha}$. The economics was calculated on the prevailing market prices. The cost of the output was increased by $25 \%$, considering higher value of organic produce. The data were subjected to ANOVA for a split plot design and means were compared using significant difference at 5\% probability using CPCS-1 data analysis package.

\section{Results and Discussion}

The cropping systems differ significantly for variables like yield, net returns and benefit cost ratio (Table 1). Tomato-coriander-pea cropping system $\left(\mathrm{CS}_{1}\right)$ recorded $17 \%, 87 \%$ and $70 \%$ increment for yield, net returns and $\mathrm{B}: \mathrm{C}$, respectively, over cauliflowercauliflower-pea system $\left(\mathrm{CS}_{2}\right)$. Crop rotation have a major impact on increasing soil structural stability, nutrient use efficiency, crop water use efficiency and soil organic matter levels, providing better weed control, and disrupting insect and disease life cycles (Carter et al., 2002, Carter et al., 2003), which may further improve soil productivity an crop yield (Galantini et al., 2000; Miglierina et al., 2000; Varvel, 2000; Kelley et al., 2003). The finding is also supported by Keith (2006) who found crop rotations as key strategies to build the soil, manage pests, and increase yields and profit. The application FYM followed by biodynamic and panchgavaya spray $\left(\mathrm{NS}_{4}\right)$ recorded highest yield, net returns and $\mathrm{B}$ : $\mathrm{C}$ as compared to other nutrient sources. Shekara $e t$ al., (2010) suggested that increased growth due to addition of various organic manures could be attributed to adequate supply of nutrients, higher uptake and recovery of applied nutrients, which in turn, must have improved synthesis and translocation of metabolites to various reproductive structures of the plant. The beneficial effect of a mix of farmyard manure and biodynamic on lettuce and Indian spices have already been documented by Bacchus (2010).

Cropping systems and nutrient sources did not change soil $\mathrm{pH}$ (Table 2). These finding corroborates with the findings of Dhull et al., (2005), who reported similar effect of crop rotations on soil reaction. The soil organic carbon and availability of $\mathrm{N}, \mathrm{P}, \mathrm{K}$ in soil was significantly influenced due to cropping systems and organic amendments. The maximum values of $\mathrm{N}, \mathrm{P}, \mathrm{K}$ was in $\mathrm{CS}_{1}$ and $\mathrm{NS}_{2}$ (Table 2). The soil organic carbon significantly changed in cropping systems and nutrient sources. Long-term field studies suggest that enhanced crop rotation complexity produces long term increases in soil organic carbon (West and Post, 2002).

The earlier workers (Karlen et al., 1994) have also reported increased soil organic carbon under cropping systems and attributed it to length of cropping system and loss of organic matter from tillage operation. Long-term manure applications increase soil organic carbon through the addition of organic matter $(\mathrm{OM})$ in the manure and through increased OM return in crop residues due to increased crop production (Whalen and Chang, 2002). The earlier study (Clark et al., 1994) also demonstrated increase in organic matter in a long term cropping sequences. Karlen et al., (1994) observed improvement in soil organic matter in cropping systems and attributed it to factors like length of cropping system and loss of organic matter from tillage operation. 
Table.1 Effect of treatments on yield and profit

\begin{tabular}{|c|c|c|c|}
\hline Treatment & Yield $\left(\mathbf{q} \mathbf{h a}^{-1}\right)$ & Net returns $\left(\right.$ Rs.ha $\left.^{-1}\right)$ & B:C \\
\hline \multicolumn{4}{|l|}{ Cropping system(CS) } \\
\hline $\mathrm{CS}_{1}=\mathrm{T}-\mathrm{Co}_{0}-\mathrm{P}$ & 21.7 & 178821 & 1.98 \\
\hline $\mathrm{CS}_{2}=\mathrm{C}-\mathrm{C}-\mathrm{P}$ & 17.8 & 95371 & 1.16 \\
\hline $\mathrm{CD}(\mathrm{P}=0.05)$ & 1.1 & 4844 & 0.16 \\
\hline \multicolumn{4}{|l|}{ Nutrient Source (NS) } \\
\hline $\begin{array}{l}\mathrm{NS}_{1}=\mathrm{RP} \text { enriched } \\
\text { FYM+VC(1:1) }\end{array}$ & 26.3 & 174614 & 2.01 \\
\hline $\mathrm{NS}_{2}=\mathrm{FYM} f b \mathrm{BD}$ & 26.6 & 176050 & 2.10 \\
\hline $\mathrm{NS}_{3}=\mathrm{NS}_{1} f b$ Panchagavya & 26.7 & 165374 & 1.67 \\
\hline $\mathrm{NS}_{4}=\mathrm{NS}_{2} \mathrm{fb}$ Panchagavya & 28.4 & 188886 & 2.35 \\
\hline $\mathbf{N S}_{5}=$ Control & 8.5 & 32879 & 0.50 \\
\hline $\mathrm{CD}(\mathrm{P}=0.05)$ & 1.5 & 7584 & 0.14 \\
\hline
\end{tabular}

$\mathrm{T}=$ tomato; $\mathrm{C}=$ cauliflower; $\mathrm{Co}=$ coriander; $\mathrm{P}=\mathrm{pea} ; \mathrm{fb}=$ followed by

Table.2 Effect of treatments on soil $\mathrm{pH}, \mathrm{OC}(\%)$, major nutrients $\left(\mathrm{kg} \mathrm{ha}^{-1}\right)$ and Micronutrients $\left(\mathrm{mg}^{-1} \mathrm{~kg}\right)$

\begin{tabular}{|c|c|c|c|c|c|c|c|c|c|}
\hline Treatment & $\mathbf{p H}$ & $\mathbf{O C}$ & $\mathbf{N}$ & $\mathbf{P}_{2} \mathbf{O}_{5}$ & $\mathrm{~K}_{2} \mathrm{O}$ & $\mathrm{Fe}$ & Mn & $\mathrm{Zn}$ & $\mathrm{Cu}$ \\
\hline \multicolumn{10}{|c|}{ Cropping system(CS) } \\
\hline $\mathrm{CS}_{1}=\mathrm{T}-\mathrm{Co}_{0}-\mathrm{P}$ & 5.7 & 0.79 & 191.6 & 58.9 & 187.2 & 52.0 & 30.8 & 2.4 & 2.0 \\
\hline $\mathrm{CS}_{2}=\mathrm{C}-\mathrm{C}-\mathrm{P}$ & 5.7 & 0.84 & 177.0 & 56.3 & 172.2 & 51.1 & 31.5 & 2.4 & 2.0 \\
\hline $\mathrm{CD}(\mathrm{P}=0.05)$ & NS & 0.01 & 0.34 & 0.48 & 0.46 & NS & NS & NS & NS \\
\hline \multicolumn{10}{|c|}{ Nutrient Sources (NS) } \\
\hline $\begin{array}{l}\mathrm{NS}_{1}=\mathrm{RP} \text { enriched } \\
\mathrm{FYM}+\mathrm{VC}(1: 1)\end{array}$ & 5.7 & 0.95 & 199.7 & 70.1 & 202.8 & 62.4 & 34.5 & 2.9 & 2.5 \\
\hline $\mathrm{NS}_{2}=\mathrm{FYM} f b \mathrm{BD}$ & 5.8 & 0.91 & 191.8 & 65.4 & 193.2 & 56.7 & 35.0 & 2.7 & 2.4 \\
\hline $\begin{array}{l}\mathrm{NS}_{3}=\mathrm{NS}_{1} \mathrm{fb} \\
\text { Panchagavya }\end{array}$ & 5.7 & 0.92 & 208.8 & 63.4 & 191.1 & 55.4 & 34.7 & 2.5 & 2.4 \\
\hline $\begin{array}{l}\mathrm{NS}_{4}=\mathrm{NS}_{2} f b \\
\text { Panchagavya }\end{array}$ & 5.7 & 0.97 & 219.9 & 69.9 & 200.8 & 60.3 & 38.1 & 2.9 & 2.6 \\
\hline $\mathrm{NS}_{5}=$ Control & 5.6 & 0.56 & 133.8 & 32.5 & 135.4 & 33.9 & 19.7 & 1.0 & 0.9 \\
\hline $\mathrm{CD}(\mathrm{P}=0.05)$ & NS & 0.04 & 8.95 & 3.49 & 5.95 & 1.35 & 2.00 & 0.12 & 0.09 \\
\hline
\end{tabular}

$\mathrm{T}=$ tomato; $\mathrm{C}=$ cauliflower; $\mathrm{Co}=$ coriander; $\mathrm{P}=\mathrm{pea} ; \mathrm{fb}=$ followed by 
Table.3 Effect of treatments on soil biological properties

\begin{tabular}{|c|c|c|c|c|c|}
\hline Treatment & Carbon biomass & Bacteria & Fungi & Actinomycetes & Phosphatase \\
\hline \multicolumn{6}{|l|}{ Cropping system(CS) } \\
\hline $\mathrm{CS}_{1}=\mathrm{T}-\mathrm{C}_{0}-\mathrm{P}$ & 27.9 & 7.6 & 5.4 & 8.3 & 15.3 \\
\hline $\mathrm{CS}_{2}=\mathrm{C}-\mathrm{C}-\mathrm{P}$ & 13.4 & 6.2 & 4.4 & 6.3 & 12.7 \\
\hline $\mathrm{CD}(\mathrm{P}=0.05)$ & 10.3 & 0.01 & 0.006 & 1.1 & 1.8 \\
\hline \multicolumn{6}{|l|}{ Nutrient Source (NS) } \\
\hline $\begin{array}{l}N_{1}=\text { RP enriched } \\
\text { FYM+VC(1:1) }\end{array}$ & 23.4 & 7.9 & 4.6 & 6.4 & 12.3 \\
\hline $\mathbf{N S}_{2}=\mathrm{FYM} f b$ BD & 27.0 & 8.2 & 4.7 & 6.4 & 13.1 \\
\hline $\mathrm{NS}_{3}=\mathrm{NS}_{1} f b$ Panchagavya & 24.9 & 8.0 & 4.3 & 6.0 & 13.4 \\
\hline $\mathrm{NS}_{4}=\mathrm{NS}_{2} f b$ Panchagavya & 36.6 & 9.3 & 5.4 & 6.9 & 14.8 \\
\hline $\mathrm{NS}_{5}=$ Control & 3.37 & 6.0 & 3.4 & 5.3 & 9.6 \\
\hline $\mathrm{CD}(\mathrm{P}=0.05)$ & 4.7 & 0.002 & 0.003 & 0.004 & 0.010 \\
\hline
\end{tabular}

$\mathrm{T}=$ tomato $\mathrm{C}=$ cauliflower; $\mathrm{Co}=$ coriander; $\mathrm{P}=\mathrm{pea} ; \mathrm{fb}=$ followed by

Carbon biomass $=$ micro gram $/ \mathrm{g}$ soil; bacteria $=10^{6} \mathrm{cfu} \mathrm{g}^{-1}$ soil; actenomycetes $=10^{5} \mathrm{cfu} \mathrm{g}^{-1}$ soil; fungi $=10^{5} \mathrm{cfu} \mathrm{g}^{-1}$ soil; phosphatase enzyme $=$ micro gram $\mathrm{p}$-nitrophenol $\mathrm{g} /$ soil

Production of appreciable quantities of carbonic acids during decomposition of organic matter mineralizes the complex organic substances, which in turn would contribute to $\mathrm{N}$ pool. An increase in available $\mathrm{N}$ by application of vermicompost and FYM was also reported by Phule (1993) and Pawar (1996).

The increase in available nitrogen due to organic matter application is also attributable to the greater multiplication of soil microbes caused by the addition of organic materials which mineralize organically bound $\mathrm{N}$ to inorganic form (Bellakki and Badanur, 1997). Tandon (1987) attributed the increase in available phosphorus with FYM application to the contribution of $\mathrm{P}$ by the organics to the soil available pool and coating of organic material on sesquioxides which reduces the phosphate fixing capacity of soil. Similar observations were also reported by Bharadwaj and Omanwar (1994). The increase in available potassium in soils of organic farms could be attributed to the direct addition of potassium to the available pool of the soil from FYM and vermicompost. The beneficial effect of FYM on the available potassium might be also ascribed to the reduction of potassium fixation (Tandon, 1988). Similar observations of increase in available potassium due to addition of organic manures were made by Grewal et al., (1981) and Bharadwaj and Omanwar (1994).

A significant increase in availability of soil micronutrients was observed among cropping systems (Table 2). The observed nonsignificant effect of cropping systems on soil micronutrients could be explained on the ground that vegetables grown in the present study were heavy feeder and nutrients availability might have exceeded crop removal. The soil micronutrients $(\mathrm{Fe}, \mathrm{Mn}, \mathrm{Zn}$ and $\mathrm{Cu}$ ) were strongly influenced due organic manure treatments. In general, the maximum improvement was in $\mathrm{NS}_{2}$. However, their content among different nutrient sources $\left(\mathrm{NS}_{1}\right.$ to $\mathrm{NS}_{4}$ ) did not vary significantly but all the nutrient sources were superior to control $\left(\mathrm{NS}_{5}\right)$. Sharma et al., (2000) attributed the increase in micronutrients in soils with addition of organics to the enhanced microbial activity and consequent release of 
complex organic substances (chelating agents) besides addition of these nutrients to the available pool on decomposition of organics.

The population of soil bacteria, fungi, actinomycetes and enzyme activity was significantly affected due to cropping systems and nutrient sources (Table 3 ). The maximum values of soil carbon biomass, bacteria, fungi, actinomycetes, phosphatase enzyme were recorded for tomato-coriander-pea in comparison to cauliflower-cauliflower-pea cropping system. The accumulation of organic carbon in cropping system might have increased soil micro flora and enzyme activity in soil. The soil microbial properties were also strongly influenced due to organic manure treatments and the highest value of all measured variables was recorded in $\mathrm{NS}_{2}$. This is in accordance with Chauhan et al., (2011), who found improvement in soil microbial properties with the application farmyard manure and compost that might be due to cumulative effect of organic manures in increasing organic carbon content of soil which acted as carbon and energy source for microbes and fermented organics in quick build- up of micro flora and fauna (Yadav and Mowade, 2004).

The results indicated that yield and improved soil health could be obtained in organic vegetable production systems using organic manure and spray of biodynamic and panchagavaya. A combine application of farmyard manure + BD 501spray could be recommended for tomato-cauliflower-pea cropping system in the Western Himalaya and the regions elsewhere having similar soil and climate conditions.

\section{Acknowledgements}

The authors are highly thankful to the Indian Council of Agricultural Research, New Delhi,
India for providing financial help under the Network Project on Organic Farming.

\section{References}

Bacchus, G.L. 2010. An evaluation of the influence of biodynamic practices including foliar-applied silica spray on nutrient quality of organic and conventionally fertilized lettuce. J. of Organic System, 5:4-13.

Bellakki, M.A. and Badanur, V.P. 1997. Longterm effect of integrated nutrient management on properties of Vertisol under dryland agriculture. Journal of the Indian Society of Soil Science, 45: 438442.

Bhardwaj, V. and Omanwar, P.K. 1994. Longterm effect of continuous rotational cropping and fertilization on crop yields and soil properties-II. Effect on EC, pH, organic matter and available nutrients of soil. Journal of the Indian Society of Soil Science, 42: 387 -392.

Bhattacharya, P., Chakraborty, G. (2005). Current status of organic farming in India and other countries. Indian Journal of Fertilizer, 1: 111-123.

Boggs, C.L., Reganold, J.P and Kennedy. 1997. A case study on biodynamic vegetable cultivation. Biol. Agric. Horti., 17:313328.

Campbell, C.A., Biederbeck, V.O., Zentner, R.P. and Lafond, G.P. 1991a. Effect of crop rotations and cultural practices on soil organic matter, microbial biomass and respiration in a thin Black Chernozem. Canadian J. Soil Sci., 71: 363-376.

Campbell, C.A., Brandt., S.A. Biederbeck, V.O., Zentner, R.P. and Schnitzer, M. 1992. Effects of crop rotations and rotation phase on characteristics of soil organic matter in a Dark Brown Chernozemic soil. Can. J. Soil Sci., 72:403-416.

Carter M.R., Kunelius H.T., Sanderson J.B., Kimpinski J., Platt H.W., Bolinder M.A. 
(2003): Productivity parameters and soil health dynamics under long-term 2-year potato rotation in Atlantic Canada. Soil Till. Res., 72: 153-168.

Carter M.R., Sanderson J.B., Ivany J.A., White R.P. (2002): Influence of rotation and tillage on forage maize productivity, weed species, and soil quality of a fine sandy loam in the cool-humid climate of Atlantic Canada. Soil Till. Res., 67: 8598.

Chauhan, P.K., Singh, V. Dhatwalia., V. and Abhishek, B. 2011. Physico-chemical and Microbial activity of soil under Conventional and Organic Agricultural Systems. Journal Chemical Pharmaceutical Research, 3:799-804.

Clark, M.S, Horwath W.R, Shennan C. and Scow K.M. 1998. Changes in soil chemical properties resulting from organic and low-input farming practices. Agronomy J., 90:662-671.

DhuII, SK., Goyal. S., Kapoor, K.K and Mundra, M.C. 2005. Crop rotation effect on soil organic matter and soil microbial properties. Indian Journal of Agriculture Research, 39: 128-132.

Doran, J.W. Sarrantonio, M. and Liebig, MA. 1996. Soil health and sustainability. Adv. Agron, 56: 1-54.

Galantini, J.A., Landriscini M.R., Iglesias J.O., Miglierina A.M., Rosell R.A. (2000). The effects of crop rotation and fertilization on wheat productivity in the Pampean semiarid region of Argentina. II. Nutrient balance, yield and grain quality. Soil Till. Res., 53: 137-144.

Gregorich, E.G. 1994.Towards a minimum data set to assess soil organic matter quality in agricultural soils.Canadian J. Soil Sci., 74:367-385.

Grewal, J.S., Sharma, R.C. and Sud, K. C. 1981.Effect of continuous application of PK-fertilizers and farm yard manure on potato yield and some soil properties. Journal of the Indian Society of Soil Science, 29: 129-131.

Gupta, R.D., Kher, D., Jalali, V.K. 2005. Organic farming: Concept and its prospective in Jammu and Kashmir Journal of Research, 1: 25-37.

Jackson, M.L. 1973. Soil chemical analysis. Prentice Hall of India Private Limited, New Adv. Agron., Delhi, Pp. 205.

Kale, R.D., Bano, K. and Satyavati, G.P. 1991. Influence of vermicompost application on growth and yield of cereals, vegetables and ornamental plants. Final Report of KSCST Project No. 67-04/verm/39B (3478) Bangalore p. 87.

Karlen, D.L., Varvel, G.E., Bullock, D.G and Cruse, R.M. 1994. Crop rotations for the $21^{\text {st }}$ century, 53:1-45.

Karthigeyan, M. and Alagesan, P. 2011. Millipede composting: A novel method for organic waste recycling. Recent Research in Science and Technology, 3: 62-67.

Keith, R.B. 2006. Crop rotations on organic farms. Center for Environmental Farming Systems. North Carolina A\&T State University.

Kelley, K.W., Long J.H., Todd T.C. 2003. Long-term crop rotations affect soybean yield, seed weight, and soil chemical properties. Field Crops Res., 83: 41-50.

Kuster, E. and Williams. S.T. 1964. Selection of media for isolation of Streptomyces. Nature, 202: 926-929.

Martun, J.P. 1950. Use of acid rose-bengal and streptomycin in plate method for estimating soil fungi. Soil Science, 69: 215-232.

Miglierina, A.M., Iglesias J.O., Landriscini M.R., Galantini J.A., Rosell R.A. 2000. The effects of crop rotation and fertilization on wheat productivity in the Pampean semiarid region of Argentina. I. Soil physical and chemical properties. Soil Tillage Res., 53: 129-135.

Minhas, R.S, Sood, A.1994. Effect of inorganic and organics on yield and nutrients uptake by three crops in rotation on in acid alfisol. Journal of Indian Society of Soil Science, 42: 257-60.

Mishra, V.K. and Sharma, R.B. 1997. Influence of integrated nutrient management on soil 
health and energy requirement of rice based cropping system. Oryza34:165-170.

Olsen, S.R., Cole, C.V. Watenabe, F.S. and Dean, L.A. 1954. Estimation of available phosphorus in soils by extraction with sodium bicarbonate, USDA circular, 939.

Pawar, R.B. 1996. Dynamics of earthworm soil plant relationship in semi-arid tropics. $\mathrm{Ph}$. D. Thesis, University of Agricultural Sciences, Dharwad. India.

Phule, K.L. 1993. Vermicompost farming practice in Maharashtra - a case study of sugarcane farming on wasteland. In : Extended Abstracts of Congress on Traditional Science and Technologies of India,28 November to 23 December, 1993, Bombay, India, pp. 10-15.

Proctor, P. 1997. Grasp the nettle, Random House New Zealand Ltd. New Zealand.

Sengar, S.S., Wade, L.J., Baghel, S.S., Singh, R. K. and Singh, G. 2000. Effect of nutrient management on rice in rainfed low land of Southeast Madhya Pradesh. Indian J. Agron., 45: 315-322.

Sharma, AR. and Mittra, BN. 1991. Direct and residual effects of organic materials and phosphorus fertilizer in rice based cropping system. Indian J. Agron.36: 299-303.

Sharma, M.P., Bali, S.V. and Gupta, D.K. 2000. Crop yield and properties of inceptisol as influenced by residue management under rice-wheat cropping sequence. Journal of the Indian Society of Soil Science, 48: 506-509.

Shekara, B.G., Sharnappa and Krishnamurthy, N. 2010. Effect of irrigation schedules on growth and yield of aerobic rice under varied levels of FYM in Cauvery Command area. Indian J. Agron, 55: 3539.

Subbiah, B.V. and Asija, C.L. 1956. A rapid procedure for the estimation of available $\mathrm{N}$ in soils. Current Science, 25: 328.

Tandon, H.L.S. 1987. Phosphorus Research and Agricultural Production in India, FDCO, New Delhi.

Tandon, H.L.S. 1988. Potassium research and agricultural production in India, FDCO, New Delhi.

Varvel, G.E. (2000): Crop rotation and nitrogen effects on normalized grain yields in a long-term study. Agron. J., 92: 938-941.

Walkley, A.J. and Black, I.A. 1934. Estimation of Soil Organic Carbon by the chromic acid titration method. Soil Science, 37: 29-38.

Yadav, A. K. and Mowade, S. M. 2004.Organic manures and compost. In: Organic farming - A ray of hope for Indian farmer. National Centre of Organic Farming, Ghaziabad, Utter Pradesh, India.

Zhao, S.W. and Haung, F.Z. 1991. The nitrogen uptake efficiency from $\mathrm{N}$ labeled chemical fertilizer in the presence of earthworm manure (cast). In: Advances in Management and Conservation of Soil FaunaEds. Veeresh, G.K., Rajagopal, D. and Virakthmath, C.A., Oxford and IBH Publishing Company Pvt. Ltd., New Delhi, pp. 539-542.

\section{How to cite this article:}

Parmar, D.K., D.R. Thakur and Gurudev Singh. 2018. Influence of Selected Organic Manures on Soil Health and Yield Sustainability of Western Himalaya Vegetable Production Systems. Int.J.Curr.Microbiol.App.Sci. 7(10): 249-256. doi: https://doi.org/10.20546/ijcmas.2018.710.026 